\title{
Anti-Biofilm Action of Nitric Oxide-Releasing Alkyl-Modified Poly(amidoamine)Dendrimers against Streptococcus mutans
}

Christopher J. Backlund, Brittany V. Worley, and Mark H. Schoenfisch*

Department of Chemistry, University of North Carolina at Chapel Hill, Chapel Hill, NC 27599

*Corresponding Author: schoenfisch@unc.edu; Tel +1 (919) 843-8714; Fax +1 (919) 962-2388

$\mathrm{CJB}$ and BVW contributed equally to this work 


\begin{abstract}
The effect of nitric oxide (NO)-releasing dendrimer hydrophobicity on Streptococcus mutans killing and biofilm disruptionwas examined at $\mathrm{pH} 7.4$ and 6.4, the latterrelevant to dental caries. Generation 1 (G1) poly(amidoamine) (PAMAM) dendrimers were modified with alkyl epoxides to generate propyl-, butyl-, hexyl-, octyl-, and dodecyl-functionalized dendrimers. The resulting secondary amines were reacted withNO to form $N$-diazeniumdiolate NO-donor modified dendrimer scaffolds (total $\mathrm{NO} \sim 1 \mu \mathrm{mol} / \mathrm{mg}$ ). The bactericidal action of the NOreleasing dendrimers against both planktonic and biofilm-based $S$. mutans proved greatest withincreasing alkyl chain length and at lower $\mathrm{pH}$. Improved bactericidal efficacy at $\mathrm{pH} 6.4$ was attributed to increased scaffoldsurface charge that enhanced dendrimer-bacteria association and ensuing membrane damage. For shorter alkyl chain (i.e., propyl and butyl) dendrimer modifications,increased antibacterial action at $\mathrm{pH} 6.4$ was due to faster NO-release kineticsfrom proton-labile $N$-diazeniumdiolate NO donors.Octyl- and dodecyl-modified PAMAM dendrimers proved most effective for eradicating $S$. mutans biofilms withNO release mitigatingdendrimer scaffold cytotoxicity.
\end{abstract}

\title{
Keywords
}

Streptococcus mutans, nitric oxide, dendrimers, dental caries 


\section{Introduction}

Dental caries is one of the most costly and prevalent diseases worldwide, with $94 \%$ of the population experiencing cavities[1, 2].The presence of Gram-positive lactobacilli and streptococci acidogenic species isconsidered a risk factor fordental caries[3-6].Cariogenic bacterialikeStreptococcus mutansmetabolize dietary sugars and produce lactic acid, which demineralizes tooth enamel[6,7]. The resulting acidicenvironment promotespreferential biofilm colonization by acidophilic species over native flora, furthering tooth decay[8]. Although the oral microbiome is complex and exhibits extreme microbial diversity, a select few bacteria are overwhelmingly acidogenic and strongly associatedwith the etiology of dental caries. These cariogenic bacteriatend to beGram-positive,often belonging to the lactobacilli or streptococci genus[2, 9, 10]. While multiple bacteria are cariogenic and linked to dental caries[9], S. mutans is considered the main etiological agent of dental caries.Current treatments are thus focused on eliminating acidogenic $S$. mutans biofilms.

Dental plaque biofilms are more difficult to treat than planktonic bacteria for a number of reasons[4, 8, 11].Secreted exopolymers create a physical boundary that limits drug (e.g., antibiotics) penetrationand preventsbiofilm eradication[11]. Phenotypic differences in surfaceattached bacteria alter potential antibiotic targets, ultimatelymitigatingdrug/bacteria interactions[11].The slower metabolic activity of biofilm bacteria also decreases antibiotic efficacy[8, 11].Lastly, antibiotic action is often inhibited by either the acidic environment or gingival fluid-derived $\beta$-lactamaseswithinoral biofilms $[8,11-13]$. Collectively, these factors requiregreater drugconcentrations to effectively eradicate dentalbiofilms at the expense of undesirable systemic side effects (e.g., pseudomembranous colitis and promoting antibioticresistant bacteria)[14]. 
Although the use of local antibioticdelivery systems has been shown to reduce systemic toxicity,continued emergence of antibiotic-resistant bacteria remains a concern,necessitatingalternativetreatments for dental caries[15, 16].Antiseptic mouthwash rinses including chlorhexidine (CHX; 0.20\% w/w) have been used to combat oral infections[17],but with modest success.Vitkov et al. reported only minor structural alterations to the exterior of mature biofilms upon CHX exposure[18].Moreover, CHX may cause changes in taste, mouth discoloration, mucosal irritation, and desquamation of the gums[19, 20].Due to the undesirable side effects and insufficient biofilm suppression associated with CHX, the search for new antiplaque therapeutics remains a continuing research focus.

Nitric oxide (NO) is an endogenous, diatomic radical that plays a pivotal role in wound healing, neurotransmission, and the immune response to pathogens[21, 22].Nitric oxide's antimicrobial activity results from its reaction with superoxide and oxygen to form peroxynitrite and dinitrogen trioxide, respectively. These species killbacteria through lipid peroxidation, DNA cleavage, and protein dysfunction[23].The multiple bactericidal pathways of $\mathrm{NO}[23,24]$ make it apotent broad-spectrum antimicrobial agent with low risk for promoting bacterial resistance[25, 26].Due to the highly reactive nature of $\mathrm{NO}$ gas, the design of storage vehicles that controllably release biocidal levels of NOis crucial to its application as a dental therapeutic[27, 28].

Our laboratory has previously reported on the synthesis of silica and dendrimer-based macromolecular NO-release scaffoldscapable of eradicating planktonic and biofilm cultures of Gram-positive, Gram-negative, and fungal pathogens[23, 29-31].More recently, we reported on thecontrolled delivery of exogenous NO to killS. mutans[32, 33]. In these studies, large instantaneous concentrations of NO were required to eradicateS. mutans. Such NO levels aregenerally toxic.To further enhance $S$. mutans killing, the use of non-depleting secondary 
biocides in combination with NO release was proposedto create dual-actionNO-releasing antibacterial agents. Carpenter et al. previouslyfunctionalized NO donor-modified silica nanoparticles with long alkyl chain quaternary ammonium (QA)groups to improve bactericidal efficacy over the solely NO-releasing silicaparticles[34]. Likewise, Worley et al. described the modification of NO-releasing poly(amidoamine) (PAMAM) dendrimers with alkyl chain QA moieties, which exhibited improved antibacterial activityover both single-action (i.e., non-NOreleasing)QA-modified dendrimers andNO-releasing QA-modified silica nanoparticles[35].Due to thereduced concentrations required to kill bacteria, NO-releasing QA-modified dendrimers proved less toxic to mouse fibroblasts than the dual-actionsilica particles[34, 35].The greaterbactericidal actionof the QA-modified NO-releasing dendrimers was attributedto both the increased cell damage via membraneintercalation of the hydrophobic alkyl chains and small size of the dendrimers allowing for greater interaction with bacteria[34-36].Subsequently, we demonstrated that short (i.e., butyl and hexyl) alkyl chain-modified dendrimers were also effective at eradicating pathogenic Pseudomonas aeruginosa and Staphylococcus aureus biofilms, with the addition of NO release facilitating anti-biofilm actionforthe macromolecules not capable of biofilm penetration [37]. Due to their increased biocidal activity against nosocomial pathogens, we hypothesized that dual-action dendrimers would be more effective at eradicating the NO-resistant cariogenic pathogen $S$. mutans than NO-release agents alone. Herein, we report the bactericidal and anti-biofilm activity of NO-releasing alkyl-modified dendrimers against cariogenic $S$. mutans as a function of alkyl chain length, $\mathrm{pH}$, and NO-release kinetics.

\section{Materials and Methods}




\subsection{Materials}

Streptococcus mutans(ATCC\#27517) and human gingival fibroblast cells (HGF-1; ATCC CRL-2014)were purchased from the American Type Tissue Culture Collection (Manassas, VA). Brain heart infusion (BHI) broth and agar were purchased from Becton, Dickinson, and Company (Franklin Lakes, NJ). Hydroxyapatite (HA) disks (5 x 2 mm) were purchased from Clarkson Chromatography Products, Inc. (South Williamsport, PA). Common laboratory salts and solvents, including Tris(hydroxymethyl)aminomethane (Tris) and Tris hydrochloride, were acquired from Fisher Scientific (Fair Lawn, NJ). Dulbecco's modified Eagle's medium (DMEM) and Dulbecco's phosphate buffered saline (PBS) were purchased from Lonza Group (Basel, Switzerland).Trypsin, penicillin streptomycin (PS), phenazine methosulfate (PMS), 3-(4,5-dimethylthiazol-2-yl)-5-(3-carboxymethoxyphenyl)-2-(4-sulfophenyl)-2Htetrazolium inner salt (MTS), fetal bovine serum (FBS),rhodamine B isothiocyanate (RITC), triethylamine (TEA), propylene oxide (PO), epoxybutane (EB), epoxyhexane (EH), epoxyoctane (EO), and epoxydodecane (ED) were purchased from Sigma-Aldrich (St. Louis, MO). Sodium methoxide (NaOMe; 5.4 M solution in methanol)wasbought from Acros Organics (Geel, Belgium). Argon (Ar), carbon dioxide $\left(\mathrm{CO}_{2}\right)$, nitrogen $\left(\mathrm{N}_{2}\right)$, and nitric oxide (NO) calibration (25.87 PPM, balance $\mathrm{N}_{2}$ ) gases were acquired from National Welders (Raleigh, NC). Nitric oxide gas $(99.5 \%)$ was purchased from Praxair (Sanford, NC). Distilled water was purified with a Millipore Milli-Q Gradient A-10 water purification system (Bedford, MA) to $\leq 6$ ppb organic content and a final resistivity of $18.2 \mathrm{~m} \Omega \cdot \mathrm{cm}$. Other solvents and reagents were analytical grade and used as received.

2.2 Synthesis of Alkyl Chain-Modified Nitric Oxide-Releasing Dendrimers 
Generation 1 (G1) poly(amidoamine) (PAMAM) dendrimer core scaffolds were synthesized as described previously[38, 39].Primaryamine-terminated G1 PAMAM dendrimers (200 mg) were then dissolved in MeOH (2 mL) with TEA andan alkyl epoxide (i.e., PO, EB, EH, EO, or ED) at a 1:1:1 molar ratio (TEA:alkyl epoxide:primary amines on the PAMAM dendrimer) to synthesize propyl-, butyl-, hexyl-, octyl-, and dodecyl-functionalized G1 PAMAM dendrimers, respectively[37]. After $3 \mathrm{~d}$ of constant stirring, the $\mathrm{MeOH}$ solvent and unreacted epoxides were removed under vacuum to purify the dendrimer product. Purfication was confirmed via ${ }^{1} \mathrm{H}$ NMR as described previously[37].

Representative ${ }^{1} \mathrm{H}$ NMR data of alkyl chain-modified G1 PAMAM included the following peaks. G1 propyl: ${ }^{1} \mathrm{H}$ NMR $(400 \mathrm{MHz}, \mathrm{MeOD}, \delta) 2.28\left(\mathrm{~s}, \mathrm{NCH}_{2} \mathrm{CH}_{2} \mathrm{C}(\mathrm{O}) \mathrm{NH}\right), 1.08-$ $1.03\left(\mathrm{t}, \mathrm{NHCH}_{2} \mathrm{CH}(\mathrm{OH}) \mathrm{CH}_{2} \mathrm{CH}_{3}\right) . \quad \mathrm{G} 1$ butyl: ${ }^{1} \mathrm{H} \mathrm{NMR}(400 \mathrm{MHz}, \mathrm{MeOD}, \delta) 2.28$ (s, $\left.\mathrm{NCH}_{2} \mathrm{CH}_{2} \mathrm{C}(\mathrm{O}) \mathrm{NH}\right), \quad 1.41-1.35 \quad\left(\mathrm{~m}, \quad \mathrm{NHCH}_{2} \mathrm{CH}(\mathrm{OH}) \mathrm{CH}_{2} \mathrm{CH}_{3}\right), \quad 0.87-0.85 \quad$ (t, $\left.\mathrm{NHCH}_{2} \mathrm{CH}(\mathrm{OH}) \mathrm{CH}_{2} \mathrm{CH}_{3}\right) . \quad \mathrm{G} 1$ hexyl: ${ }^{1} \mathrm{H} \quad \mathrm{NMR} \quad(400 \quad \mathrm{MHz}, \quad \mathrm{MeOD}, \quad \delta) \quad 2.28 \quad(\mathrm{~s}$, $\left.\mathrm{NCH}_{2} \mathrm{CH}_{2} \mathrm{C}(\mathrm{O}) \mathrm{NH}\right), \quad 1.34-1.20 \quad\left(\mathrm{~m}, \quad \mathrm{NHCH}_{2} \mathrm{CH}(\mathrm{OH}) \mathrm{C}\left(\mathrm{H}_{2}\right)_{3} \mathrm{CH}_{3}\right), \quad$ 0.85-0.81 (t, $\left.\mathrm{NHCH}_{2} \mathrm{CH}(\mathrm{OH}) \mathrm{C}\left(\mathrm{H}_{2}\right)_{3} \mathrm{CH}_{3}\right) . \quad$ G1 octyl: $\quad{ }^{1} \mathrm{H} \quad \mathrm{NMR} \quad(400 \quad \mathrm{MHz}, \quad \mathrm{MeOD}, \quad \delta) \quad 2.29 \quad$ (s, $\left.\mathrm{NCH}_{2} \mathrm{CH}_{2} \mathrm{C}(\mathrm{O}) \mathrm{NH}\right), \quad 1.35-1.23 \quad\left(\mathrm{~m}, \quad \mathrm{NHCH}_{2} \mathrm{CH}(\mathrm{OH})\left(\mathrm{CH}_{2}\right)_{5} \mathrm{CH}_{3}\right), \quad 0.83-0.80 \quad$ (t, $\left.\mathrm{NHCH}_{2} \mathrm{CH}(\mathrm{OH}) \mathrm{C}\left(\mathrm{H}_{2}\right)_{5} \mathrm{CH}_{3}\right) . \quad \mathrm{G} 1$ dodecyl: ${ }^{1} \mathrm{H} \quad \mathrm{NMR} \quad(400 \mathrm{MHz}, \mathrm{MeOD}, \quad \delta) \quad 2.30 \quad$ (s, $\left.\mathrm{NCH}_{2} \mathrm{CH}_{2} \mathrm{C}(\mathrm{O}) \mathrm{NH}\right), \quad 1.40-1.20 \quad\left(\mathrm{~m}, \quad \mathrm{NHCH}_{2} \mathrm{CH}(\mathrm{OH})\left(\mathrm{CH}_{2}\right)_{9} \mathrm{CH}_{3}\right), \quad 0.83-0.80 \quad$ (t, $\left.\mathrm{NHCH}_{2} \mathrm{CH}(\mathrm{OH}) \mathrm{C}\left(\mathrm{H}_{2}\right)_{5} \mathrm{CH}_{3}\right)$.

Secondary amines on the alkyl-modified dendrimers were converted to $\mathrm{N}$ diazeniumdiolate NO donors by combining alkyl-modified G1PAMAM dendrimers (30mg) with 1 molar equivalent $\mathrm{NaOMe}$ (with respect to the primary amines onthe unmodified G1 PAMAM scaffold)in $1 \mathrm{~mL}$ of varying ratios of methanol $(\mathrm{MeOH})$ to tetrahydrofuran (THF) based on alkyl 
chain length: 100\% MeOH (G1 propyl, butyl), 8.5:1.5 MeOH:THF (G1 hexyl), 3:2 MeOH:THF (G1 octyl, or 2:3 MeOH:THF (G1 dodecyl). The mixtures wereplaced in a stainless steel Parr reaction vessel, flushed with Ar three times to a pressure of 7 bar, and then filled with Ar three times for longer durations $(10 \mathrm{~min})$ to remove trace oxygen from the solutions. Following deoxygenation, the reaction chamber was filled with $\mathrm{NO}$ and held at 10 bar with constant stirring. After $3 \mathrm{~d}$, the chamber was flushed again with Ar three times at short durations prior to extended Ar purges( $3 \times 10 \mathrm{~min})$ to remove unreacted NO. The solutions were then collected and excess solvent was removed under vacuum. The NO-releasing dendrimers were resuspended in $\mathrm{MeOH}$ and stored at $-20{ }^{\circ} \mathrm{C}$ until further use.

\subsection{Characterization of Nitric Oxide Release}

Nitric oxide release was measured in real time using a Sievers 280i Chemiluminescence Nitric Oxide Analyzer (Boulder, CO) [40].Nitric oxide release parameters were subsequently determined via chemiluminescence, including total NO release $(\mathrm{t}[\mathrm{NO}])$, total NO released after 2 $\mathrm{h}\left(\mathrm{t}[\mathrm{NO}]_{2 \mathrm{~h}}\right)$, NO-release half-life $\left(\mathrm{t}_{1 / 2}\right)$, and maximum NO flux ([NO $\left.]_{\max }\right)[41]$.Briefly, NOreleasing dendrimers ( 0.5 or $1.0 \mathrm{mg}$ aliquots in methanol) were added to a flask containing 30 $\mathrm{mL}$ of deoxygenated phosphate-buffered saline (PBS; $\left.37{ }^{\circ} \mathrm{C}\right)$ ateither $\mathrm{pH} 7.4$ or 6.4 . Nitrogen was bubbled continuously through the solution to carry liberated NO to the analyzer at a flow rate of $80 \mathrm{~mL} / \mathrm{min}$. The $\mathrm{NO}$ analysis was terminated when $\mathrm{NO}$ levels fell to $<10 \mathrm{ppb} / \mathrm{mg}$ dendrimer.

\subsection{Planktonic Bactericidal Assays}


To evaluate the bactericidal efficacy of the alkyl-modified dendrimers against planktonic S. mutans, the $2 \mathrm{~h}$ minimum bactericidal concentration $\left(\mathrm{MBC}_{2 \mathrm{~h}}\right)$ (i.e., the minimum dendrimer concentration required to achieve a 3-log reduction inbacterialviability) was determined under static growth conditions. Briefly, bacteriawas cultured overnight at $37{ }^{\circ} \mathrm{C}$ in $\sim 3 \mathrm{~mL}$ BHI broth from a frozen stock $\left(15 \%(\mathrm{v} / \mathrm{v})\right.$ glycerol in PBS at $\left.-80{ }^{\circ} \mathrm{C}\right)$. The next day, a $1 \mathrm{~mL}$ aliquot of the resulting bacterial suspension was inoculated into $50 \mathrm{~mL}$ fresh $\mathrm{BHI}$ broth and grown at $37{ }^{\circ} \mathrm{C}$ with moderate shaking to a concentration of $10^{8}$ colony forming units per milliliter $(\mathrm{CFU} / \mathrm{mL})$ as confirmed by optical density (OD; $600 \mathrm{~nm})$. The bacteriawere then collected by centrifugation (2355 x g; $10 \mathrm{~min}$ ), resuspended in distilled water, and diluted to $10^{6} \mathrm{CFU} / \mathrm{mL}$ in eitherTrisPBS(pH 7.4) with $1 \%(\mathrm{v} / \mathrm{v})$ BHI broth or PBS ( $\mathrm{pH} 6.4)$ with $5 \%(\mathrm{v} / \mathrm{v})$ BHI broth. Tris-PBS buffer was prepared by supplementing PBS with $100 \mathrm{mM}$ Tris base and adjusting the $\mathrm{pH}$ to 7.4.The bacterial solutions were then added to vials containing NO-releasing or non-NOreleasing dendrimers $(0.006-48 \mathrm{mg} / \mathrm{mL})$, mixed, and incubated at $37{ }^{\circ} \mathrm{C}$ with moderate shaking.Untreated controls (blanks) were included in each experiment to ensure the bacteria remained viable (at $10^{6} \mathrm{CFU} / \mathrm{mL}$ ) over the $2 \mathrm{~h}$ assay. After $2 \mathrm{~h}$, the bacteria suspensions were diluted and plated on BHI agar using an IUL Eddy Jet spiral plater (Farmingdale, NY). Plates were incubated at $37{ }^{\circ} \mathrm{C}$ for $72 \mathrm{~h}$ before viable colonies were enumerated using a Flash \& Go colony counter (IUL; Farmingdale, NY). The dendrimer concentration resulting in bacterial viability below $2.5 \times 10^{3} \mathrm{CFU} / \mathrm{mL}$ (the limit of detection for this plating method) from the initial $10^{6} \mathrm{CFU} / \mathrm{mL}$ culture was taken to be the $\mathrm{MBC}_{2 \mathrm{~h}}[42]$.

\subsection{Biofilm Eradication Assays}


Suspensions of $S$. mutans $\left(10^{8} \mathrm{CFU} / \mathrm{mL}\right)$ were prepared as described above and collected by centrifugation ( $2355 \times \mathrm{g} ; 10 \mathrm{~min}$ ). Following centrifugation, bacteria were resuspended in distilled water and diluted to $10^{6} \mathrm{CFU} / \mathrm{mL}$ in $40 \mathrm{~mL}$ of $50 / 50 \mathrm{BHI} /$ distilled water with $1 \% \mathrm{w} / \mathrm{v}$ glucose and sucrose. The bacterialsuspension $(3 \mathrm{~mL})$ was added to a 12-well culture plate with each well containing one hydroxyapatite (HA) disk.Each disk was incubated with bacteriaat 37 ${ }^{\circ} \mathrm{C}$ and gentle shaking. After $24 \mathrm{~h}$, the disks were removed, rinsed in distilled water, and added to test suspensions of NO-releasing or non-NO-releasing dendrimers $(0.25-64 \mathrm{mg} / \mathrm{mL})$ in TrisPBS (pH7.4) or PBS (pH6.4). Untreated control biofilms (blanks) were included in each experiment to ensure the biofilms remained viable over the $2 \mathrm{~h}$ assay. After $2 \mathrm{~h}$ of moderate shaking under static growth conditions, the disks were removed, rinsed in distilled water again, and sonicated in $3 \mathrm{~mL}$ of distilled water at lowpower for $10 \mathrm{~min}$. The resultingbacterialsolutions were then plated on BHI agar using the aforementioned spiral plating system, and incubated further at $37{ }^{\circ} \mathrm{C}$. After $72 \mathrm{~h}$, viable colonies were enumerated as described above. The dendrimer concentration resulting in a 3-log or greater reduction in viable bacteria to below $2.5 \mathrm{x}$ $10^{4} \mathrm{CFU} / \mathrm{mLwas}$ determined to be the $2 \mathrm{~h}$ minimum biofilm eradication concentration $\left(\mathrm{MBEC}_{2 \mathrm{~h}}\right)$.

\subsection{Confocal Microscopy to Assess Dendrimer-Bacteria Association}

Fluorescently labeled G1 PAMAM dendrimers were synthesized as described previously[29, 35, 43]. Briefly, $100 \mathrm{mg}$ G1 PAMAM were added to a vial containing one molar equivalent of RITC (3.75 mg) per mole of dendrimer in methanol $(2 \mathrm{~mL})$. One mole equivalent of triethylamine (with respect to the number of dendrimer primary amines) was then added to the vial and the solution was stirred for $24 \mathrm{~h}$ in the dark. After removal of the solvent under vacuum, 
dendrimers were dissolved in water, purified via dialysis against water at room temperature $(2 \mathrm{~L}$ DI water versus $5 \mathrm{~mL}$ sample; 3-4 water changes over $1 \mathrm{~d}$ ), and then lyophilized. The dendrimers were functionalized with alkylchainsper the above procedure in the dark to create fluorescentlylabeled butyl-modified G1 PAMAM dendrimers.

S. mutans was cultured as described above and diluted to $10^{6} \mathrm{CFU} / \mathrm{mL}$ in Tris-PBS $(\mathrm{pH}$ 7.4) or PBS ( $\mathrm{pH}$ 6.4), each containing 3\% (v/v) BHI broth. Aliquots of the bacteria solution were incubated in a glass bottom confocal dish (MatTek Corporation; Ashland, MA) at $37^{\circ} \mathrm{C}$ for 45 min. A Zeiss 510 Meta inverted laser scanning confocal microscope with a $543 \mathrm{~nm} \mathrm{HeNe}$ excitation laser ( $1.0 \mathrm{~mW}, 25.0 \%$ intensity) and a $560-615 \mathrm{~nm}$ band-pass filter was used to obtain fluorescence images of the RITC-modified dendrimers. Both bright field and fluorescence images were collected using an N.A. 1.2 C-Apochromat water immersion lens with a 40x objective. Solutions of RITC-labeled butyl-modified dendrimers $(200 \mu \mathrm{g} / \mathrm{mL})$ in Tris-PBS or PBS $(1.5 \mathrm{~mL})$ were added to $1.5 \mathrm{~mL}$ of the respective bacteria solution in the glass confocal dish to achieve a final concentration of $100 \mu \mathrm{g} / \mathrm{mL}$. Images were collected in $2 \mathrm{~min}$ intervals to temporally monitor dendrimer association with the bacteria. The image colors were inverted for clarity using ImageJ software.

\subsection{In Vitro Cytotoxicity}

Human gingival fibroblasts (HGF-1) were grown in DMEM supplemented with 10 vol\% FBS and $1 \mathrm{wt} \%$ PS and incubated in 5 vol $\% \mathrm{CO}_{2}$ under humidified conditions at $37{ }^{\circ} \mathrm{C}$. After reaching $80 \%$ confluency, the cells were trypsinized with $1 \mathrm{~mL} 0.25 \%$ trypsin for $15-20 \mathrm{~min}$ with light agitation. After removal from the plate, cells were diluted using $11 \mathrm{~mL}$ DMEM and seeded onto tissue culture-treated polystyrene $96-$ well plates at a density of $10^{4}$ cells $/ \mathrm{mL}$. The 
plates were then incubated for $6 \mathrm{~d}$ at $37^{\circ} \mathrm{Cusing}$ fresh media every second day.The supernatant was then aspirated and replaced with $200 \mu \mathrm{L}$ of fresh growth medium and $50 \mu \mathrm{L}$ of varying concentrations of dendrimer in PBS. Dimethyl sulfoxide (10\%) and $50 \mu \mathrm{L}$ PBS were used as positive and negative controls, respectively. After $2 \mathrm{~h}$ incubation at $37^{\circ} \mathrm{C}$, the supernatant was aspirated and $120 \mu \mathrm{L}$ of a mixture of DMEM/MTS/PMS (105/20/1, v/v/v) was added to each well. After $1.5 \mathrm{~h}$ incubation at $37^{\circ} \mathrm{C}$, the absorbance of the colored solutions was quantified at $490 \mathrm{~nm}$ using a Thermoscientific Multiskan EX plate reader (Waltham, MA). The mixture of DMEM/MTS/PMS and untreated cells were used as a blank and control, respectively. Results were expressed as percentage of relative cell viability as follows:

$$
\% \text { Cell Viability }=\left[\left(\mathrm{Abs}_{490}-\mathrm{Abs}_{\text {blank }}\right) /\left(\mathrm{Abs}_{\mathrm{control}}-\mathrm{Abs}_{\text {blank }}\right)\right] \mathrm{x} 100 \%
$$

Eq. 1

Statistical analysis of the resulting cell viabilities was performed using a two-tailed student's ttest with $\mathrm{p}<0.05$ ( $95 \%$ confidence interval).

\section{Results}

\subsection{Characterization of Nitric Oxide-Releasing Dendrimers}

Generation 1 poly(amidoamine) (PAMAM) dendrimers were modified with alkyl chains of varying length (i.e., propyl, butyl, hexyl, octyl, or dodecyl) via a ring-opening reaction at the peripheral primary amines, and the resulting secondary amines were subsequently modified with $\mathrm{N}$-diazeniumdiolate NO donors at high pressure (10 bar NO) under basic conditions (Scheme 1)[35, 44]. Nitric oxide release was measured in PBS at both $\mathrm{pH} 7.4$ and 6.4 to mimic the more acidic conditions in the oral cavity (Table 1)[45].Of note, we observed little to no change in dendrimer NO-release characteristics between pH 5.4 and6.4 (data not shown). However, maintaining biofilm integrity in the absence of treatment at $\mathrm{pH} 5.4$ was considerably more 
difficult than at $\mathrm{pH}$ 6.4. The acidic experiments were thus carried out at $\mathrm{pH} 6.4$. At $\mathrm{pH} \mathrm{7.4,} \mathrm{the}$ total NO released $(0.90-1.12 \mu \mathrm{mol} / \mathrm{mg})$ and maximum instantaneous NO concentrations (3980$5700 \mathrm{ppb} / \mathrm{mg}$ ) were similar for each dendrimer system, independent of alkyl chain modification, while the NO-release half-life increased slightly ( 21 to $37 \mathrm{~min}$ ) with longer alkyl chains (i.e., increased hydrophobicity). Of importance, similar total NO payloads were delivered at $2 \mathrm{~h}(\sim 0.9$ $\mu \mathrm{mol} / \mathrm{mg}$ ) regardless of alkyl chain length, although NO release continued for several hours (durations of 7-9 h). Alternatively, faster NO release was observed under acidic conditions ( $\mathrm{pH}$ 6.4) as evidenced by the greater maximum NO flux (15100-26000 ppb/mg) and the shorter NOrelease half-life (4-9 $\mathrm{min})$. Despite the faster NO-release kinetics, the $2 \mathrm{~h}$ total NO releasewas comparable at pH $6.4(\sim 1.0 \mu \mathrm{mol} / \mathrm{mg})$ compared to $\mathrm{pH} 7.4(\sim 0.9 \mu \mathrm{mol} / \mathrm{mg})$.

\subsection{Bactericidal Efficacy of Alkyl-Modified Dendrimers}

The bactericidal efficacy of alkyl-modified G1 PAMAM dendrimers against planktonic cultures of $S$. mutans was evaluated at both $\mathrm{pH} 7.4$ and 6.4 by determining the minimum bactericidal concentration $\left(\mathrm{MBC}_{2 \mathrm{~h}}\right)$ required to elicit a 3-log reduction in bacterial viability relative to untreated cultures (Table 2). At pH 7.4, the non-NO-releasing short alkyl chain (i.e., propyl and butyl) dendrimers were ineffective at killing S. mutans, with no reduction in bacterial viability up to a concentration of $48 \mathrm{mg} / \mathrm{mL}$. Compared to the shorter alkyl chains, the longer alkyl chain (i.e., hexyl, octyl, and dodecyl) dendrimers were considerably more bactericidal $\left(\mathrm{MBC}_{2 \mathrm{~h}}\right.$ values $\leq 2 \mathrm{mg} / \mathrm{mL}$ ). Under more acidic conditions ( $\mathrm{pH} 6.4$ ), little to no antibacterial action was again observed for the propyl-modified dendrimers $\left(\mathrm{MBC}_{2 \mathrm{~h}}>48 \mathrm{mg} / \mathrm{mL}\right)$. The bactericidal efficacy of butyl-modified dendrimers was improved at $\mathrm{pH} 6.4$, but still required large dendrimer concentrations $(32 \mathrm{mg} / \mathrm{mL})$ to elicit killing. In contrast, the bactericidal action 
of longer alkyl chain-modified dendrimers was enhanced at lower $\mathrm{pH}$ (6.4), as evidenced by the reduced $\mathrm{MBC}_{2 \mathrm{~h}}$ values relative to those at $\mathrm{pH} 7.4$ (Table 2).

The incorporation of NO release capabilities did not improve the biocidal action of the hexyl-, octyl-, or dodecyl-modified dendrimer scaffolds at either $\mathrm{pH}$ (Table 2). The addition of NO release moderately improved the bactericidal activity for propyl- and butyl-modified dendrimers at $\mathrm{pH} 7.4$, albeit requiring large doses of $\mathrm{NO}(39.4$ and $46.6 \mu \mathrm{mol} / \mathrm{mL}$, respectively) to elicit a 3-log reduction in bacterial viability $\left(\mathrm{MBC}_{2 \mathrm{~h}}=48 \mathrm{mg} / \mathrm{mL}\right)$. In contrast to the long alkyl chain-modified dendrimers, the antibacterial action of NO-releasing propyl- and butylmodified dendrimers was significantly enhanced at $\mathrm{pH}$ 6.4, exhibiting bactericidal concentrations 6-fold lower at pH $6.4(8 \mathrm{mg} / \mathrm{mL})$ versus pH $7.4(48 \mathrm{mg} / \mathrm{mL})$ for both NO-releasing propyl- and butyl-modified dendrimers. The lower $\mathrm{MBC}_{2 \mathrm{~h}}$ values translate to reduced bactericidal NO doses for propyl-modified (39.4 to $8.7 \mu \mathrm{mol} / \mathrm{mL}$ ) and butyl-modified (46.6 to $7.8 \mu \mathrm{mol} / \mathrm{mL}$ ) dendrimers.

\subsection{Anti-Biofilm Activity of Alkyl-Modified Dendrimers}

The ability of NO-releasing and control alkyl-modified dendrimers required to elicit at least a 3-log reduction in bacterial viability for $S$. mutans biofilms grown on hydroxyapatite disks $\left(\mathrm{MBEC}_{2 \mathrm{~h}}\right)$ was also evaluated at $\mathrm{pH} 7.4$ and 6.4. As expected, the anti-biofilm activity for control (non-NO-releasing) propyl- and butyl-modified dendrimers was negligible at pH 7.4 $\left(\mathrm{MBEC}_{2 \mathrm{~h}}>64 \mathrm{mg} / \mathrm{mL}\right.$ ) (Table 3). Biofilm eradication was substantially improved by increasing the alkyl chain length, with significantly reduced $\mathrm{MBEC}_{2 \mathrm{~h}}$ values for hexyl- $(8 \mathrm{mg} / \mathrm{mL})$ and octyl- and dodecyl-modified dendrimers $(\leq 2 \mathrm{mg} / \mathrm{mL})$ at both $\mathrm{pH} 6.4$ and 7.4. Similar to 
planktonic studies, however, the combination of NO release and long alkyl chains (i.e., hexyl, octyl, and dodecyl) did not improve biofilm killing over control dendrimers at either $\mathrm{pH}$.

Alternatively, the addition of NO release capabilities improved the anti-biofilm activity of propyl- and butyl-modified dendrimers at $\mathrm{pH} 7.4$, with $\mathrm{MBEC}_{2 \mathrm{~h}}$ values of 64 and $48 \mathrm{mg} / \mathrm{mL}$, respectively, corresponding to significant bactericidal NO doses $(52.5$ and $46.6 \mu \mathrm{mol} / \mathrm{mL}$, respectively). However, anti-biofilm action was significantly enhanced for the NO-releasing short alkyl chain dendrimers at $\mathrm{pH}$ 6.4, with NO-releasing propyl- and butyl-modified dendrimers eradicating biofilms at $8 \mathrm{mg} / \mathrm{mL}(\sim 8-9 \mu \mathrm{mol} \mathrm{NO} / \mathrm{mg})$.

\subsection{In Vitro Cytotoxicity of Alkyl-Modified Dendrimers}

Human gingival fibroblasts (HGF-1), a common cell line used to evaluate the toxicity of dental composites $[46,47]$, were exposed to NO-releasing and control dendrimers for $2 \mathrm{~h}$ at the maximum concentrations required to kill S. mutans biofilms(Figure 1). Short chain propylmodified dendrimer controls were non-toxic to L929 fibroblasts (>95\% cell viability relative to untreated cells) at the concentrations required for anti-biofilm activity (8 and $64 \mathrm{mg} / \mathrm{mL}$ at $\mathrm{pH}$ 6.4 and 7.4, respectively). Nitric oxide-releasing propyl dendrimers exhibited greater toxicity to mammalian cells, reducing cell viability by approximately 50 and $70 \%$ at 8 and $64 \mathrm{mg} / \mathrm{mL}$, respectively. While the butyl-modified control dendrimers were relatively non-toxic at $8 \mathrm{mg} / \mathrm{mL}$ ( $90 \%$ cell viability), substantial toxicity was observed at higher concentrations. Further, the addition of NO release to the butyl-modified scaffold proved lethal to mammalian cells ( $0 \%$ cell viability), even at the concentration necessary for biofilm eradication at pH $6.4(8 \mathrm{mg} / \mathrm{mL})$.

The cells also showed poor tolerance to hexyl-modified control dendrimers ( 4\% cell viability) at $8 \mathrm{mg} / \mathrm{mL}$, with the NO-releasing hexyl dendrimers proving similarly lethal as the short chain modifications ( $0 \%$ cell viability). The octyl- and dodecyl-modified control 
dendrimers exhibited similar toxicity, with cell viabilities of $8 \pm 1$ and $4 \pm 1 \%$, respectively. Interestingly, the addition of NO to the octyl- and dodecyl-modified dendrimers reduced their toxicity, with cell viabilities of $17 \pm 4$ and $19 \pm 3 \%$, respectively.

\section{Discussion}

We have previously reported on the modification of PAMAM dendrimers to create secondary amine-functionalized scaffolds that store and spontaneously release NO[29].The chemistry ofNO storage was also combined with non-depleting, membrane-disrupting QA biocides and shorter (i.e., butyl and hexyl) alkyl chains, which proved highly effective at killing nosocomial pathogens (i.e., Pseudomonasaeruginosa and Staphylococcus aureus)[35, 37]. To further investigate the effects of alkyl chain length independent of functional group density (i.e., dendrimer generation), modifications consisting of shorter and longer alkyl chains were tethered to the G1 PAMAM scaffold.In the present study, we investigated the effects of exterior dendrimer hydrophobicity, $\mathrm{pH}$, and NO release on the antibacterial and anti-biofilm activityof NO-releasing propyl-, butyl-, hexyl-, octyl-, and dodecyl-modified G1 PAMAM dendrimers against $S$. mutans, an etiological agent of dental caries.

In addition to physiological $\mathrm{pH}$ (7.4), NO release from alkyl-modified G1 PAMAM dendrimers was characterized at $\mathrm{pH} 6.4$ to more accurately mimic the in vivo environment associated with dental caries. While the NO-releasing dendrimers exhibited similar initial NO fluxes and total NO payloads at $\mathrm{pH} 7.4$, the NO-release half-lives were somewhat extended for the longer octyl and dodecyl alkyl chains over the shorter modifications. The slight increase in NO-release half-life for the longer alkyl chains was attributed to a decrease in water diffusion to the proton-labile $\mathrm{N}$-diazeniumdiolate NO donors with increasing hydrophobicity. The total NO 
released after $2 \mathrm{~h}$ was similar $(\sim 0.9 \mu \mathrm{mol} / \mathrm{mg})$ regardless of alkyl chain length, allowing us to examine the effect of exterior hydrophobicity on bactericidal efficacy and anti-biofilm activity independent of NO-release totals. As expected, faster NO release was observed under acidic conditions due to the proton-initiated decomposition of $N$-diazeniumdiolate NO donors, resulting in greater initial $\mathrm{NO}$ fluxes and shorter half-lives. As with $\mathrm{pH} 7.4$, the dodecyl-modified dendrimers exhibited a slightly longer half-life than the other modifications, although all dendrimers exhibited half-lives of less than $10 \mathrm{~min}$. Despite the faster NO-release kinetics, the 2 $\mathrm{h}$ total $\mathrm{NO}$ releasewas comparable at $\mathrm{pH} 6.4(\sim 1.0 \mu \mathrm{mol} / \mathrm{mg})$ compared to $\mathrm{pH} 7.4(\sim 0.9$ $\mu \mathrm{mol} / \mathrm{mg}$ ), corresponding to the NO dose delivered during $2 \mathrm{~h}$ bactericidal assays.

Bactericidal action was evaluated against planktonic and biofilm cultures of S. mutans at both $\mathrm{pH} 7.4$ and 6.4 under static conditions. While neither propyl- nor butyl-modified dendrimers were capable of eradicating planktonic cultures of S. mutans at $\mathrm{pH} 7.4$, the bactericidal action of the butyl-modified dendrimers was slightly improved at lower $\mathrm{pH}$. However, large concentrations of butyl-modified dendrimers were still required for $S$. mutans eradication, as minimal membrane intercalation by the shorter, less hydrophobic tails limits the bacterial membrane damage caused by these scaffolds[34, 35].Alternatively, the longer alkyl chain (i.e., hexyl, octyl, and dodecyl) modifications were considerably more bactericidal at substantially lower concentrations. The dramatic improvement in antibacterial activity is attributed to the membrane intercalation of these longer chains causingsignificant membrane damage[29, 34, 35, 37].Further, the bactericidal efficacy of these longer chains was also enhanced at lower $\mathrm{pH}$, requiring lower biocidal concentrations to eradicate $S$. mutans than at $\mathrm{pH}$ 7.4. The increased bactericidal action at $\mathrm{pH} 6.4$ is likely due to greater protonation of pendant amines on the 
dendrimer scaffold (i.e., increased positive surface charge) promoting more efficient dendrimerbacteria association andimproving membrane intercalation of the hydrophobic chains.

Dendrimer diffusion to bacteria in real-time was visualized with confocal microscopy to confirm enhanced dendrimer-bacteria association at lower $\mathrm{pH}$ (Figure 2). At $\mathrm{pH}$ 6.4, a substantial fluorescence signal from RITC-labeled butyl-modified dendrimers associating with $S$. mutanswasobservedafteronly 30 minof dendrimer exposure. This signal continued to increase in intensity up to $60 \mathrm{~min}$. In contrast, the fluorescence signal intensity at $\mathrm{pH} 7.4$ was negligible, and did not change through the same period of study. The greater fluorescence signal at $\mathrm{pH} 6.4$ both initially and over time suggests more rapid and extensive dendrimer-bacteria association under acidic conditions.Enhanced dendrimer-bacteria association would translate to more extensive bacterial damage as alkyl chain-induced death is contact-based[34, 35, 37]. This hypothesis is consistent withthe lower $\mathrm{MBC}_{2 \mathrm{~h}}$ values observed for butyl-, hexyl-, octyl-, and dodecyl-modified dendrimers at $\mathrm{pH} 6.4$ compared to $\mathrm{pH}$ 7.4.

The addition of NO-release capabilities had little impact on the antibacterial action of the longer alkyl chain-modified dendrimers at either $\mathrm{pH}$. Thehydrophobicalkyl chains of these PAMAM analogues likely compromise the bacterial membrane prior to significant accumulation of intracellular NO, thus limiting NO-induced killing[35].Upon lowering the $\mathrm{pH}$ to 6.4, similar behavior was again observed, with NO-releasing and control dendrimers exhibitingno difference in killing efficiency. The highly efficient membrane disruption of hydrophobic alkyl chains clearly precludes intracellular NO accumulation, alleviating NO-mediated cell death[35].

For the propyl- and butyl-modified dendrimers, the addition of NO release moderately improved their biocidal action at $\mathrm{pH} 7.4$ but still required large $\mathrm{NO}$ doses to achieve bacterial killing. However, lowering the $\mathrm{pH}$ significantly enhanced the bactericidal efficacy of these short 
chain dendrimers, resulting in reduced bactericidal $\mathrm{NO}$ doses from $\sim 40 \mu \mathrm{mol} / \mathrm{mL}$ to $\sim 8$ $\mu \mathrm{mol} / \mathrm{mL}$. This dramatic improvement in antibacterial action for the NO-releasing propyl- and butyl-modified dendrimers at $\mathrm{pH} 6.4$ over both the NO-releasing dendrimer at $\mathrm{pH} 7.4$ and the non-NO-releasing controls at $\mathrm{pH} 6.4$ suggests the increased biocidal activity is due to faster NOrelease kinetics afforded by the lower $\mathrm{pH}$. Indeed, while the bacterial association of butylmodified dendrimers wasenhanced at lower $\mathrm{pH}$ (Figure 2), the lack of antibacterial activity by the butyl-modified controlsat $\mathrm{pH} 6.4$ suggests minimal membrane disruption via alkyl chain intercalation. Similarly,thepropyl-modified controls were relatively ineffective at $\mathrm{pH}$ 6.4. The disparity in killing efficiency between the NO-releasing and control propyl- and butyl-modified dendrimers at $\mathrm{pH}$ 6.4unequivocally demonstrates that rapid $\mathrm{NO}$ release in combination with enhanced dendrimer-bacteria associationareresponsible for the improved bactericidal efficacy. These findingssuggest thatlarge instantaneous NO concentrations are more effective for eradicating $S$. mutans, an important consideration when using solely NO-releasing macromolecular scaffolds to kill S. mutans and possibly other cariogenic bacteria as well[32]. Although the assay medium was supplemented with nutrient broth, we elected not to evaluate bacteria killing in artificial saliva (e.g., high protein concentration) to avoid NO scavenging. Nevertheless, the antibacterial action of the dendrimer scaffold would likely not changeunder such conditions.

Although studying microbes in planktonic, nutrient-rich batch cultures isuseful for initial drug activity screening, in vivo infections are typically caused by bacterial biofilms[5, 48].Dental caries is associated with persistent biofilms composed of mainly streptococci and lactobacilli,with $S$. mutans considered a primary causative agent[2, 7, 10, 49-51].Thus, the eradication of cariogenic S. mutans biofilms is importantfor the treatment of dental caries. As 
such, we evaluated the ability of alkyl chain-modified dendrimers to eradicate $S$. mutans biofilms grown on hydroxyapatite disks to simulate tooth enamel at pH 6.4 and 7.4[52].

As expected, non-NO-releasing propyl- and butyl-modified dendrimers were incapable of eradicating $S$. mutans biofilms at $\mathrm{pH} 7.4$, most likely due to insufficient membrane disruption by the shorter alkyl chains $[34,35]$. Biofilm killing was again significantly enhanced for the longer alkyl chain modifications. Similar to planktonic killing, this enhancement in anti-biofilm activity is attributed toincreased membrane disruption and biofilm penetrationby the long hydrophobic chains compared to minimal membrane damage caused by shorter alkyl chains[34, 35, 37].Interestingly, the anti-biofilm action of the longer alkyl chains was not improved at lower $\mathrm{pH}$. The addition of NO release to the longer alkyl chain-modified dendrimers did not improve the biofilm eradication capabilities over the control dendrimers at either $\mathrm{pH}$, most likely due to efficientmembrane disruption precluding significant intracellular accumulation of NO andmitigating NO-mediated killing[35].Similarly, the difference in biofilm killing for longer alkyl chain-modifiedNO-releasing dendrimers at $\mathrm{pH} 7.4$ versus 6.4 was negligible, indicating that greater dendrimer-bacteria association in combination with faster NO releasedoes not enhance biofilm eradication capabilities for these modifications.

Nitric oxide-releasing propyl- and butyl-modified dendrimers exhibited slightly increased anti-biofilm capabilities over control dendrimers at pH 7.4, albeit at large bactericidal NO doses. Reducing the $\mathrm{pH}$ to 6.4 , however, significantly enhanced the biofilm eradication capabilities of the NO-releasing short chain dendrimers. The bactericidal NO doses required to eradicate the $S$. mutans biofilms were decreased from 52.5 to $8.7 \mu \mathrm{mol} / \mathrm{mL}$ for propyl- and 46.6 to $7.8 \mu \mathrm{mol} / \mathrm{mL}$ for butyl-modified dendrimers. The dramatic improvement in biofilm eradication cannot be attributed to increased membrane damage via greater dendrimer-bacteria association, as control 
propyl- and butyl-modified dendrimers displayed little to no antibacterial activityat either $\mathrm{pH}$. Rather, the enhanced anti-biofilm activity of propyl- and butyl-modified NO-releasing dendrimers at $\mathrm{pH} 6.4$ must be the result of more efficient dendrimer-bacteria association (Figure 2)combined with faster NO-release kinetics (Table 1). This dramatically improved killing of $S$. mutans biofilms could have implications for the future design of NO-releasing materials to treat cariogenic dental plaque biofilms.

While the control propyl modifications were non-toxic at large dendrimer concentrations, the addition of $\mathrm{NO}$ release to these dendrimers resulted in increased toxicity to human gingival fibroblast cells. Similarly, while the butyl-modified control dendrimers were relatively non-toxic at lower concentrations $(8 \mathrm{mg} / \mathrm{mL})$, their NO-releasing counterparts were completely lethal to HGF-1 cells. This toxicity is attributed to the largedose of NOrequired to eradicate S. mutans biofilms, as evidenced by the tolerance of mammalian cells to the control dendrimers at similar concentrations.

Unlike the short chain modifications, hexyl-modified control dendrimers exhibited significant toxicity at anti-biofilm concentrations, likely the result of membrane disruption by the hydrophobic alkyl chains. Not surprisingly, the addition of NO release to these dendrimers resulted in additional toxicity. The octyl- and dodecyl-modified control dendrimers exhibited similar toxicity to the hexyl modifications, again attributed to significant membrane disruption caused by the long alkyl chains. Interestingly, the NO-releasing long alkyl chain modifications were appreciably less toxic at equivalent concentrations. We have previously observedthat low levels of NO are capable of improving cell viability for NO-release systems over controls[34, 35].The reduced toxicity observed for NO-releasing long alkyl chain dendrimers, while maintaining superior anti-biofilm activity, demonstrates their potential utility as dental caries 
therapeutics. Indeed, the toxicity levels exhibited by the NO-releasing octyl- and dododecylmodified dendrimers is comparable to that of clinical doses of chlorhexidine, which have been found to reduce HGF-1 cell viability by $\sim 80 \%$ after $2 \mathrm{~h}[33]$.

In conclusion, the bactericidal and anti-biofilm activity of NO-releasing PAMAM dendrimers was increased with greater exterior hydrophobicity at both $\mathrm{pH} 7.4$ and 6.4. Improved bactericidal action was observed at lower $\mathrm{pH}(6.4)$ as a result of enhanced dendrimer-bacteria association and faster NO-release kinetics. Long alkyl chain (e.g., octyl and dodecyl) dendrimer modificationswere characterized as having superior anti-biofilm activity. The NO release from these dendrimer scaffolds partially mitigated the cytotoxicity of the dendrimer to mammalian cells.Collectively, these results demonstrate the potential utility of NO-releasing long alkyl chain-modified dendrimers as anti-biofilm agents for the treatment of dental caries.Studies involving poly-microbial biofilms that more closely resemble dental plaqueare necessary to better predict the clinical utility of alkyl chain-modified NO-releasing dendrimers.

\section{Acknowledgements}

This research was supported by the National Science Foundation (DMR 1104892). The authors thank Michael Chua of the Michael Hooker Microscopy Facility at the University of North Carolina at Chapel Hill for his assistance with confocal microscopy.

\section{Disclosure}

The corresponding author declares competing financial interest. Mark Schoenfisch is a co-founder and a member of the board of directors, and maintains a financial interest in Novan 
Therapeutics, Inc. Novan Therapeutics is commercializing macromolecular nitric oxide storage and release vehicles for dermatological clinical indications.

\section{References}

[1] Featherstone JD. The science and practice of caries prevention. J Am Dent Assoc 131 (2000) 887-900.

[2] Gibbons R, Houte J. Dental caries. Annu Rev Med 26 (1975) 121-36.

[3] Harris R, Nicoll AD, Adair PM, Pine CM. Risk factors for dental caries in young children: a systematic review of the literature. Community Dent Health 21 (2004) 71-85.

[4] Costerton J, Stewart PS, Greenberg E. Bacterial biofilms: A common cause of persistent infections. Science 284 (1999) 1318-22.

[5] Parsek MR, Singh PK. Bacterial biofilms: An emerging link to disease pathogenesis. Annu Rev Microbiol 57 (2003) 677-701.

[6] Sbordone L, Bortolaia C. Oral microbial biofilms and plaque-related diseases: Microbial communities and their role in the shift from oral health to disease. Clin Oral Invest 7 (2003) 1818.

[7] Krzyściak W, Jurczak A, Kościelniak D, Bystrowska B, Skalniak A. The virulence of Streptococcus mutans and the ability to form biofilms. Eur J Clin Microbiol Infect Dis (2013) 117.

[8] Hojo K, Nagaoka S, Ohshima T, Maeda N. Bacterial interactions in dental biofilm development. J Dent Res 88 (2009) 982-90.

[9] da Silva BR, de Freitas VAA, Nascimento-Neto LG, Carneiro VA, Arruda FVS, de Aguiar ASW, et al. Antimicrobial peptide control of pathogenic microorganisms of the oral cavity: a review of the literature. Peptides 36 (2012) 315-21.

[10] Selwitz RH, Ismail AI, Pitts NB. Dental caries. Lancet 369 (2007) 51-9.

[11] Marsh P. Dental plaque as a microbial biofilm. Caries Res 38 (2004) 204-11.

[12] Herrera D, Winkelhoff A, Dellemijn-Kippuw N, Winkel E, Sanz M. $\beta$-lactamase producing bacteria in the subgingival microflora of adult patients with periodontitis. A comparison between Spain and The Netherlands. J Clin Periodontol 27 (2000) 520-5.

[13] Brook I, Pazzaglia G, Coolbaugh JC, Walker RI. In-vivo protection of group A $\beta$ haemolytic streptococci from penicillin by $\beta$-lactamase-producing bacteroides species. J Antimicrob Chemother 12 (1983) 599-606. 
[14] Radvar M, Pourtaghi N, Kinane D. Comparison of 3 periodontal local antibiotic therapies in persistent periodontal pockets. J Periodontol 67 (1996) 860-5.

[15] Williams RC, Paquette DW, Offenbacher S, Adams DF, Armitage GC, Bray K, et al. Treatment of periodontitis by local administration of minocycline microspheres: A controlled trial. J Periodontol 72 (2001) 1535-44.

[16] Kinane D, Radvar M. A six-month comparison of three periodontal local antimicrobial therapies in persistent periodontal pockets. J Periodontol 70 (1999) 1-7.

[17] Van Strydonck D, Timmerman M, Van Der Velden U, Van Der Weijden G. Plaque inhibition of two commercially available chlorhexidine mouthrinses. J Clin Periodontol 32 (2005) 305-9.

[18] Vitkov L, Hermann A, Krautgartner W, Herrmann M, Fuchs K, Klappacher M, et al. Chlorhexidine-induced ultrastructural alterations in oral biofilm. Microsc Res Tech 68 (2005) 85-9.

[19] Charbonneau D, Snider A. Reduced chlorhexidine tooth stain coverage by sequential administration of monoperoxyphthalic acid in the beagle dog. J Dent Res 76 (1997) 1596-601.

[20] Gürgan CA, Zaim E, Bakirsoy I, Soykan E. Short-term side effects of $0.2 \%$ alcohol-free chlorhexidine mouthrinse used as an adjunct to non-surgical periodontal treatment: A doubleblind clinical study. J Periodontol 77 (2006) 370-84.

[21] Bogdan C. Nitric oxide and the immune response. Nat Immunol 2 (2001) 907-16.

[22] Bredt DS. Endogenous nitric oxide synthesis: Biological functions and pathophysiology. Free Radical Res 31 (1999) 577-96.

[23] Hetrick EM, Shin JH, Stasko NA, Johnson CB, Wespe DA, Holmuhamedov E, et al. Bactericidal efficacy of nitric oxide-releasing silica nanoparticles. ACS Nano 2 (2008) 235-46.

[24] Fang FC. Antimicrobial reactive oxygen and nitrogen species: concepts and controversies. Nat Rev Microbiol 2 (2004) 820-32.

[25] Privett BJ, Broadnax AD, Bauman SJ, Riccio DA, Schoenfisch MH. Examination of bacterial resistance to exogenous nitric oxide. Nitric Oxide 26 (2012) 169-73.

[26] Schairer DO, Chouake JS, Nosanchuk JD, Friedman AJ. The potential of nitric oxide releasing therapies as antimicrobial agents. Virulence 3 (2012) 271-9.

[27] Riccio DA, Schoenfisch MH. Nitric oxide release: Part I. Macromolecular scaffolds. Chem Soc Rev 41 (2012) 3731-41.

[28] Carpenter AW, Schoenfisch MH. Nitric oxide release: Part II. Therapeutic applications. Chem Soc Rev 41 (2012) 3742-52. 
[29] Lu Y, Slomberg DL, Shah A, Schoenfisch MH. Nitric oxide-releasing amphiphilic poly (amidoamine) (PAMAM) dendrimers as antibacterial agents. Biomacromolecules 14 (2013) 3589-98.

[30] Lu Y, Slomberg DL, Sun B, Schoenfisch MH. Shape- and nitric oxide flux-dependent bactericidal activity of nitric oxide-releasing silica nanorods. Small 9 (2013) 2189-98.

[31] Hetrick EM, Shin JH, Paul HS, Schoenfisch MH. Anti-biofilm efficacy of nitric oxidereleasing silica nanoparticles. Biomaterials 30 (2009) 2782-9.

[32] Backlund C, Worley B, Sergesketter A, Schoenfisch M. Kinetic-dependent killing of oral pathogens with nitric oxide. J Dent Res 94 (2015) 1092-8.

[33] Backlund CJ, Sergesketter AR, Offenbacher S, Schoenfisch MH. Antibacterial efficacy of exogenous nitric oxide on periodontal pathogens. J Dent Res 93 (2014) 1089-94.

[34] Carpenter AW, Worley BV, Slomberg DL, Schoenfisch MH. Dual action antimicrobials: Nitric oxide release from quaternary ammonium-functionalized silica nanoparticles. Biomacromolecules 13 (2012) 3334-42.

[35] Worley BV, Slomberg DL, Schoenfisch MH. Nitric oxide-releasing quaternary ammoniummodified poly (amidoamine) dendrimers as dual action antibacterial agents. Bioconjugate Chem 25 (2014) 918-27.

[36] Yang X, Shang H, Ding C, Li J. Recent developments and applications of bioinspired dendritic polymers. Polymer Chemistry 6 (2015) 668-80.

[37] Worley BV, Schilly KM, Schoenfisch MH. Anti-biofilm efficacy of dual-action nitric oxide-releasing alkyl chain modified poly(amidoamine) dendrimers. Molecular pharmaceutics 12 (2015) 1573-83.

[38] Tomalia D, Baker H, Dewald J, Hall M, Kallos G, Martin S, et al. A new class of polymers: Starburst-dendritic macromolecules. Polym J 17 (1985) 117-32.

[39] Tomalia DA. Birth of a new macromolecular architecture: Dendrimers as quantized building blocks for nanoscale synthetic polymer chemistry. Prog Polym Sci 30 (2005) 294-324.

[40] Hetrick EM, Schoenfisch MH. Analytical chemistry of nitric oxide. Annual review of analytical chemistry (Palo Alto, Calif) 2 (2009) 409.

[41] Coneski PN, Schoenfisch MH. Nitric oxide release: Part III. Measurement and reporting. Chem Soc Rev 41 (2012) 3753-8.

[42] Breed RS, Dotterrer W. The number of colonies allowable on satisfactory agar plates. J Bacteriol 1 (1916) 321.

[43] Sun B, Slomberg DL, Chudasama SL, Lu Y, Schoenfisch MH. Nitric oxide-releasing dendrimers as antibacterial agents. Biomacromolecules 13 (2012) 3343-54. 
[44] Lu Y, Sun B, Li C, Schoenfisch MH. Structurally diverse nitric oxide-releasing poly(propylene imine) dendrimers. Chem Mater 23 (2011) 4227-33.

[45] Chin MY, Busscher HJ, Evans R, Noar J, Pratten J. Early biofilm formation and the effects of antimicrobial agents on orthodontic bonding materials in a parallel plate flow chamber. The European Journal of Orthodontics 28 (2006) 1-7.

[46] Geurtsen W, Lehmann F, Spahl W, Leyhausen G. Cytotoxicity of 35 dental resin composite monomers/additives in permanent $3 \mathrm{~T} 3$ and three human primary fibroblast cultures. Journal of biomedical materials research 41 (1998) 474-80.

[47] Moharamzadeh K, Van Noort R, Brook IM, Scutt AM. Cytotoxicity of resin monomers on human gingival fibroblasts and HaCaT keratinocytes. dental materials 23 (2007) 40-4.

[48] Costerton JW, Cheng K, Geesey GG, Ladd TI, Nickel JC, Dasgupta M, et al. Bacterial biofilms in nature and disease. Annu Rev Microbiol 41 (1987) 435-64.

[49] Radcliffe CE, Akram NC, Hurrell F, Drucker DB. Effects of nitrite and nitrate on the growth and acidogenicity of Streptococcus mutans. J Dent 30 (2002) 325-31.

[50] Gaikwad R, Sokolov I. Silica nanoparticles to polish tooth surfaces for caries prevention. J Dent Res 87 (2008) 980-3.

[51] Kim Y, Lee D, Lee J, Lim Y. The effect of silver ion-releasing elastomers on mutans streptococci in dental plaque. Korean J Orthodont 42 (2012) 87-93.

[52] Apella M, Susana V, García-Rodenas M, Blesa M, Morando P. Synthetic hydroxyapatite as a surface model of dental enamel and dentine J Arg Chem Soc 97 (2009) 109-18. 
Table 1. Characterization of NO-releasing alkyl-modified G1 PAMAM dendrimers in PBS (37 $\left.{ }^{\circ} \mathrm{C}\right)$ at $\mathrm{pH} 7.4$ and 6.4 by means of a chemiluminescent nitric oxide analyzer. ${ }^{\mathrm{a}}$

\begin{tabular}{|c|c|c|c|c|c|}
\hline pH & $\begin{array}{l}\text { Dendrimer } \\
\text { Modification }\end{array}$ & $\begin{array}{c}\mathrm{t}[\mathrm{NO}]^{\mathrm{b}} \\
(\mu \mathrm{mol} / \mathrm{mg})\end{array}$ & $\begin{array}{c}\mathrm{t}[\mathrm{NO}]_{2 \mathrm{~h}}^{\mathrm{c}} \\
(\mu \mathrm{mol} / \mathrm{mg})\end{array}$ & $\begin{array}{c}t_{1 / 2}^{d} \\
(\min )\end{array}$ & {$[\mathrm{NO}]_{\max }^{\mathrm{e}}(\mathrm{ppb} / \mathrm{mg})$} \\
\hline \multirow{5}{*}{7.4} & Propyl & $0.90 \pm 0.20$ & $0.82 \pm 0.10$ & $21.8 \pm 3.9$ & $5700 \pm 2290$ \\
\hline & Butyl & $1.06 \pm 0.10$ & $0.97 \pm 0.10$ & $21.7 \pm 5.0$ & $4930 \pm 690$ \\
\hline & Hexyl & $0.98 \pm 0.11$ & $0.90 \pm 0.14$ & $23.5 \pm 5.5$ & $4340 \pm 1070$ \\
\hline & Octyl & $1.07 \pm 0.13$ & $0.88 \pm 0.08$ & $29.8 \pm 5.4$ & $3980 \pm 940$ \\
\hline & Dodecyl & $1.12 \pm 0.10$ & $0.90 \pm 0.05$ & $37.3 \pm 6.3$ & $4200 \pm 950$ \\
\hline \multirow{5}{*}{6.4} & Propyl & $1.09 \pm 0.19$ & $1.09 \pm 0.19$ & $4.2 \pm 0.8$ & $26000 \pm 3780$ \\
\hline & Butyl & $0.98 \pm 0.22$ & $0.98 \pm 0.22$ & $4.4 \pm 0.5$ & $21400 \pm 6960$ \\
\hline & Hexyl & $1.04 \pm 0.34$ & $1.03 \pm 0.34$ & $4.3 \pm 0.2$ & $22600 \pm 6220$ \\
\hline & Octyl & $1.06 \pm 0.24$ & $1.04 \pm 0.24$ & $5.0 \pm 0.1$ & $20500 \pm 4840$ \\
\hline & Dodecyl & $1.10 \pm 0.31$ & $1.07 \pm 0.29$ & $8.9 \pm 0.8$ & $15100 \pm 1850$ \\
\hline
\end{tabular}

${ }^{a}$ Results shown as mean \pm standard deviation for $\mathrm{n} \geq 3$ pooled experiments. ${ }^{\mathrm{b}}$ Total amount of NO released. ${ }^{\mathrm{c}}$ Total amount of NO released after $2 \mathrm{~h} .{ }^{\mathrm{d}}$ Time to release half of total NO payload. ${ }^{\mathrm{e}}$ Maximum NO flux achieved. 
Table 2. Minimum bactericidal concentrations $\left(\mathrm{MBC}_{2 \mathrm{~h}}\right)$ and bactericidal NO doses of alkylmodified G1 PAMAM dendrimers against planktonic $S$. mutans at $\mathrm{pH}=7.4$ and $\mathrm{pH}=6.4 .^{\mathrm{a}}$

\begin{tabular}{|c|c|c|c|c|}
\hline & \multicolumn{2}{|c|}{$\mathrm{pH}=7.4$} & \multicolumn{2}{|c|}{$\mathrm{pH}=6.4$} \\
\hline & $\begin{array}{c}\mathrm{MBC}_{2 h} \\
(\mathrm{mg} / \mathrm{mL})\end{array}$ & $\begin{array}{c}\text { NO Dose } \\
(\mu \mathrm{mol} / \mathrm{mL})\end{array}$ & $\begin{array}{c}\mathrm{MBC}_{2 h} \\
(\mathrm{mg} / \mathbf{m L})\end{array}$ & $\begin{array}{c}\text { NO Dose } \\
(\mu \mathrm{mol} / \mathrm{mL})\end{array}$ \\
\hline Propyl & $>48$ & & $>48$ & \\
\hline Propyl-NO & 48 & 39.4 & 8 & 8.7 \\
\hline Butyl & $>48$ & & 32 & \\
\hline Butyl-NO & 48 & 46.6 & 8 & 7.8 \\
\hline Hexyl & 2 & & 1 & \\
\hline Hexyl-NO & 2 & 1.8 & 1 & 1.0 \\
\hline Octyl & 0.05 & & 0.012 & \\
\hline Octyl-NO & 0.1 & 0.1 & 0.025 & $<0.1$ \\
\hline Dodecyl & 0.05 & & 0.025 & \\
\hline Dodecyl-NO & 0.05 & 0.1 & 0.025 & $<0.1$ \\
\hline
\end{tabular}

${ }^{a}$ Results of $\mathrm{n} \geq 3$ pooled experiments. 
Table 3. Minimum biofilm eradication concentrations $\left(\mathrm{MBEC}_{2 \mathrm{~h}}\right)$ and bactericidal NO doses of alkyl-modified G1 PAMAM dendrimers against $S$. mutans biofilms at $\mathrm{pH} 7.4$ and 6.4. ${ }^{\mathrm{a}}$

\begin{tabular}{|c|c|c|c|c|}
\hline & \multicolumn{2}{|c|}{$\mathrm{pH}=7.4$} & \multicolumn{2}{|c|}{$\mathrm{pH}=6.4$} \\
\hline & $\begin{array}{l}\mathrm{MBEC}_{2 h} \\
(\mathrm{mg} / \mathrm{mL})\end{array}$ & $\begin{array}{c}\text { NO Dose } \\
(\mu \mathrm{mol} / \mathrm{mL})\end{array}$ & $\begin{array}{l}\mathrm{MBEC}_{2 h} \\
(\mathrm{mg} / \mathrm{mL})\end{array}$ & $\begin{array}{c}\text { NO Dose } \\
(\mu \mathrm{mol} / \mathrm{mL})\end{array}$ \\
\hline Propyl & $>64$ & & $>48$ & \\
\hline Propyl-NO & 64 & 52.5 & 8 & 8.7 \\
\hline Butyl & $>64$ & & 48 & \\
\hline Butyl-NO & 48 & 46.6 & 8 & 7.8 \\
\hline Hexyl & 8 & & 8 & \\
\hline Hexyl-NO & 8 & 7.2 & 8 & 8.2 \\
\hline Octyl & 2 & & 2 & \\
\hline Octyl-NO & 2 & 1.8 & 2 & 2.1 \\
\hline Dodecyl & 2 & & 1 & \\
\hline Dodecyl-NO & 2 & 1.8 & 2 & 2.1 \\
\hline
\end{tabular}

${ }^{a}$ Results of $n \geq 3$ pooled experiments. 

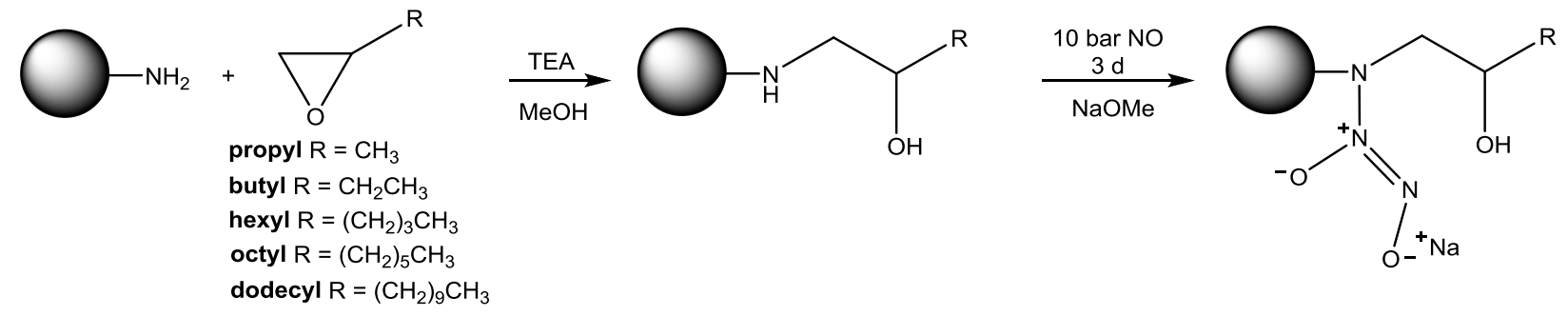

Scheme 1. Reaction of PAMAM scaffold with epoxides to yield alkyl-modified dendrimers, followed by reaction with high pressures of NO to yield dual-action, NO-releasing dendrimers. 


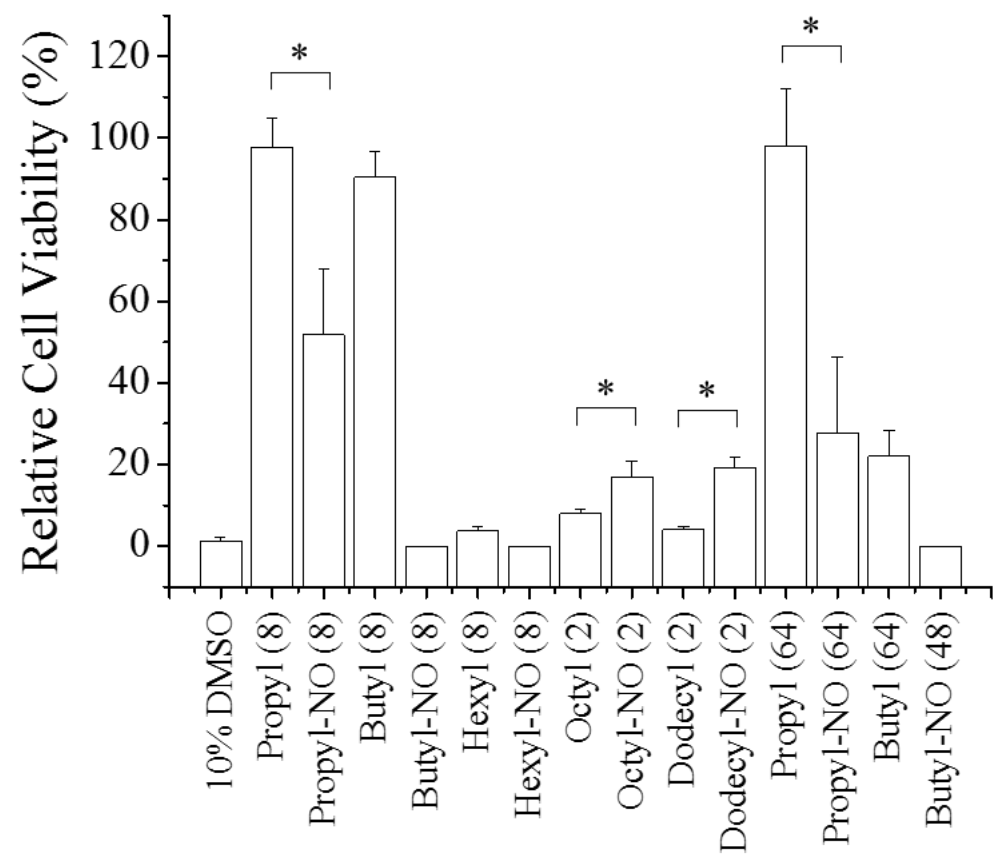

Figure 1. Cytotoxicity of NO-releasing and non-NO-releasing dendrimers against HGF-1 human gingival fibroblasts at the concentrations required for biofilm eradication. $10 \%$ DMSO was used as a positive control. Numbers following each dendrimer modification (i.e., 2, 8, 48, and 64) represent the $\mathrm{MBEC}_{2 \mathrm{~h}}$ in $\mathrm{mg} / \mathrm{mL}$. Error bars represent the standard deviation of the mean. For all values, $n \geq 3$ replicate measurements. Asterisk indicates significant differences $(p<0.05)$ using two-tailed student's t-test. 


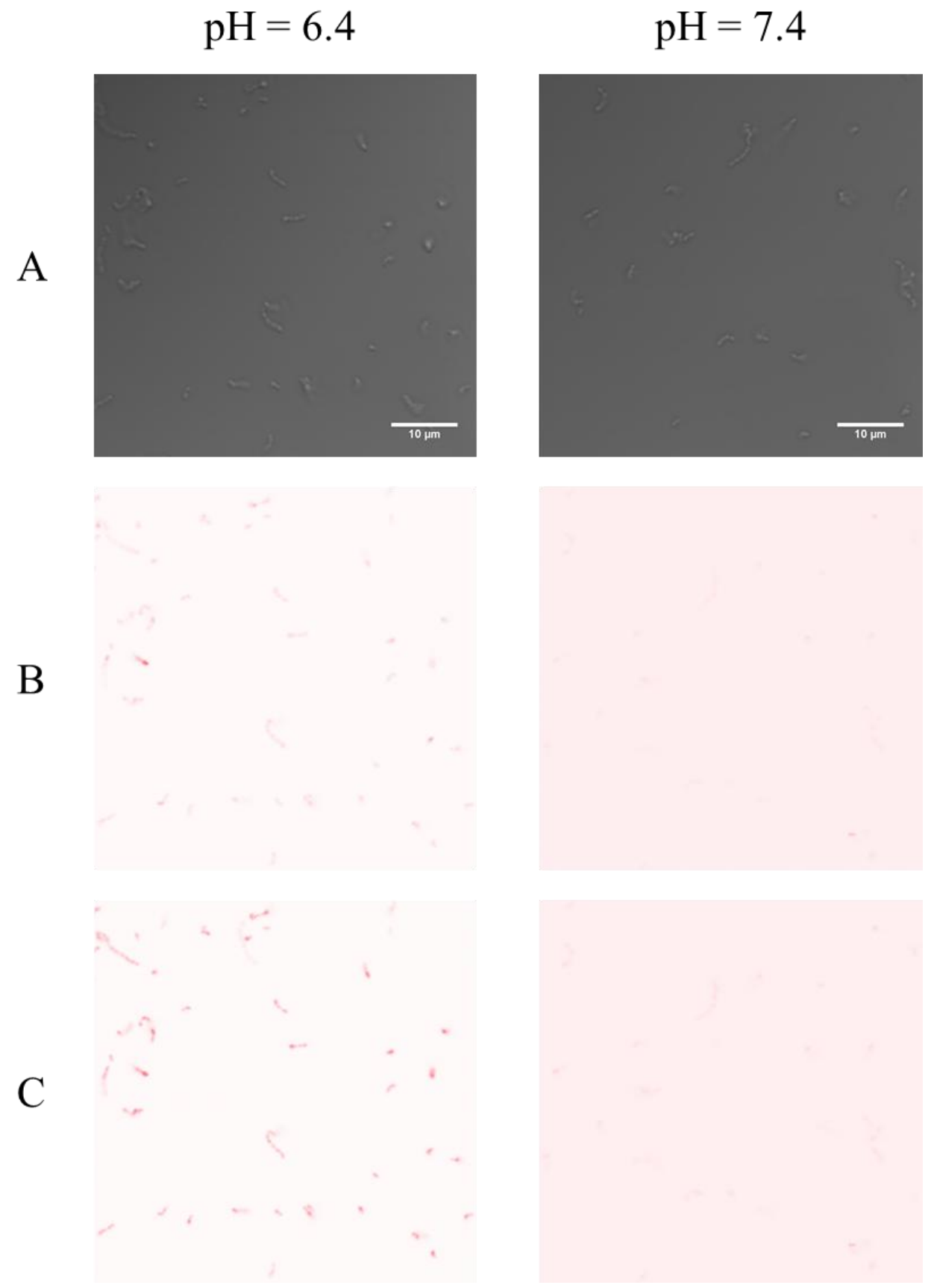

Figure 2. Confocal microscopy images of planktonic S. mutans exposed to $100 \mu \mathrm{g} / \mathrm{mL}$ RITClabeled G1 butyl dendrimers at pH 6.4 and 7.4 imaged at (A) 0, (B) 30, and (C) 60 min. Image colors modified and inverted for clarity. Scale bar $=10 \mu \mathrm{m}$. 


\section{G1 butyl/NO} dendrimers

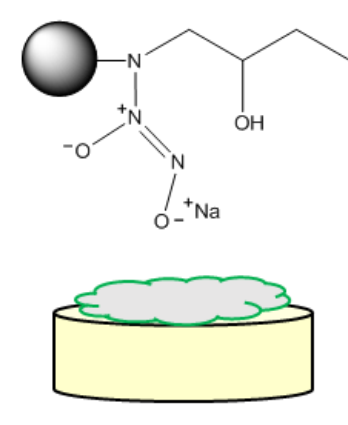

S. mutans biofilms

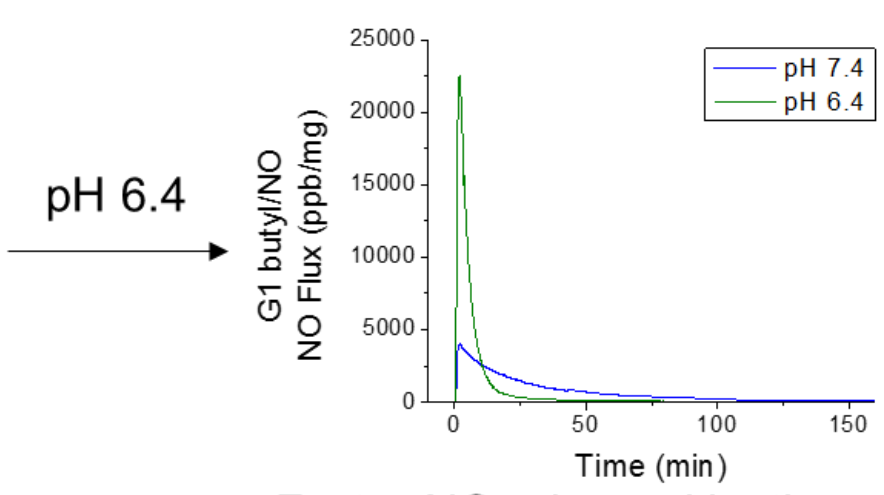

Faster NO-release kinetics

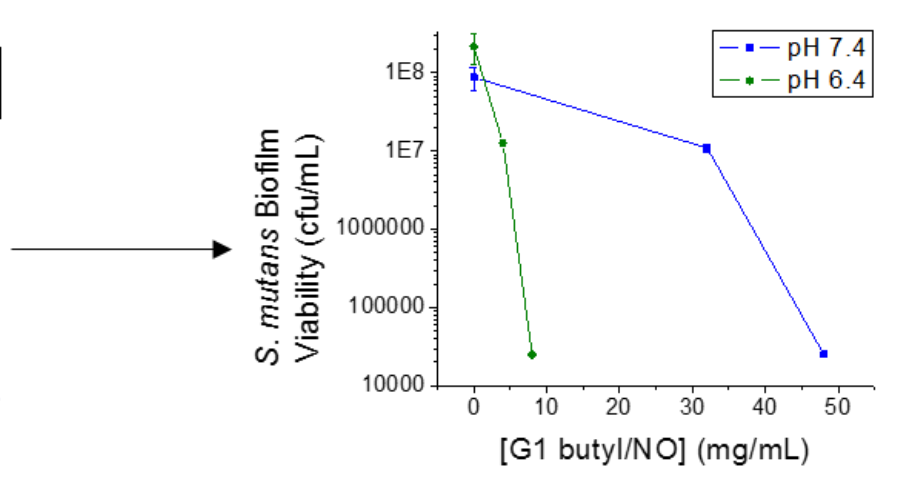

Enhanced biofilm killing 